Janusz Myszczyszyn

(Zachodniopomorski Uniwersytet

Technologiczny w Szczecinie)

\title{
POWSTANIE I ROZWÓJ KOLEI ŻELAZNYCH W PROWINCJI POMORZE JAKO WYRAZ AKTYWNOŚCI LOKALNYCH ŚRODOWISK I SEKTORA PUBLICZNEGO
}

\section{Wstęp}

$\mathrm{B}$ adania naukowe z XX wieku są potwierdzeniem, że koleje, jako jedna z ważniejszych innowacji w XIX wieku i zarazem okresu przewrotu technicznego, były ważnym elementem industrializacji i siłą napędową dokonujących się zmian gospodarczych, społecznych i politycznych w Europie i USA ${ }^{1}$. W przypadku Niemiec przeprowadzone przez autora badania własne z wykorzystaniem modelowania ekonometrycznego potwierdziły powyższą tezę, również w odniesieniu do roli kolejnictwa we wzroście gospodarczym².

Ernest Behm w opracowaniu z 1867 roku Die modernen Verkehrsmittel Dampfschiffe, Eisenbahnen, Telegrafen dostrzega przełomowe znaczenie ,trojga dzieci epoki": kolei żelaznych, parowców i telegrafu. Zastosowanie do napędu silnika parowego w parze $\mathrm{z}$ telegrafem wywołało istną rewolucję we wszystkich obszarach życia ludzkiego - zarówno materialnych jak i intelektualnych, co przyczyniło się bez wątpienia do wyzwolenia procesów globalizacyjnych w gospodarce światowej ${ }^{3}$.

\footnotetext{
${ }^{1}$ R. Fogel, A Quantitative Approach to the Study of Railroads in American Economic Growth: A Report of Some Preliminary Findings, „Journal of Economic History” 1962, 22, 163/197: A. Fishlow, American Railroads and the Transformation of the Antebellum Economy, Cambridge, MA: Harvard University Press 1965; R. Fogel, Railroads and American Economic Growth: Essays in Econometric History. Baltimore 1964; W. W. Rostow, The Stages of Economic Growth - A Non Communist Manifesto, Cambridge 1960. R. Fremdling, Eisenbahnen und deutsches Wirtschaftswachstum 1840-1879. Ein Beitrag zur Entwicklungstheorie und zur Theorie der Infrastruktur, Dortmund 1985.

2 J. Myszczyszyn, Wplyw kolei żelaznych na wzrost gospodarczy Niemiec (1840-1913), Łódź 2013, autor również obliczył społeczne oszczędności dla niemieckiego sektora kolejowego, które są relatywnie niewielkie i wyniosły dla roku $1909-2,08-2,32 \%$ PKB (s. 171-179).

${ }^{3}$ E. Behm, Die modernen Verkehrsmittel: Dampfschiffe, Eisenbahnen, Telegraphen; eine geographisch-statistische Übersicht mit historischen und volkswirtschaftlichen Notizen mit einer Telegraphen- und Dampfschifffahrts-Karte der Erde und einer Kommunikations-Karte von Central-Europa, Gotha 1867, s. 1 i n.; J. Myszczyszyn, Rozwój transportu i wymiany międzynarodowej a pierwsza fala globalizacji gospodarczej, „Kultura-Historia-Globalizacja” 2014, nr 15, s. 139-152.
} 
Głównym celem założonym przez autora jest ukazanie rozwoju sieci kolejowej w Królestwie Prus od pierwszych prób rozbudowy (lata 30. XIX w.) do wybuchu I wojny światowej. ze szczególnym uwzględnieniem prowincji Pomorze.

Budowa nowych szlaków kolejowych, a szczególnie w rolniczych i mało zaludnionych prowincjach wschodnich królestwa Prus, jest przejawem (początkowo) aktywnej działalności lokalnych kół oraz późniejszej aktywnej działalności rządu, parlamentu i państwa, a tym samym uczestnictwo sektora publicznego w rozbudowie, a począwszy od lat siedemdziesiątych XIX wieku nacjonalizacji kolei i powstaniu licznych kolei wąskotorowych.

Prowincja Pomorze pozostawała dość specyficznym regionem, o niskim zaludnieniu, dużym znaczeniu rolnictwa, do tego zacofanym gospodarczo. Mimo to począwszy od lat dziewięćdziesiątych XIX wieku rozbudowano sieć kolei III rzędu, co może być dowodem na to, że gęstość linii kolejowych (głównych i pobocznych) była na tle pozostałych prowincji pruskich niedostateczna, a kolej wąskotorowa uzupełniła i tak niedostatecznie rozwiniętą infrastrukturę komunikacyjną.

Autor wykorzystał w przygotowaniu artykułu współczesne opracowania oraz starsze z okresu XIX wieku, włączając także analizą danych statystycznych.

\section{Początki kolejnictwa w Europie i Prusach - przegląd}

Już w kilka lat po kongresie wiedeńskim powstały plany sieci kolejowej, która połączyłaby w całość obszar państw niemieckich. Impulsem były pierwsze udane próby z wykorzystaniem maszyny parowej i koni (linia Stockton-Darlington (1825), Liverpool-Manchester (1826), poczynione w Anglii. Sam G. Stephenson - uważany był początkowo za dziwaka przy pierwszych próbach zastąpienia siły mięśni zwierzęcych siłą maszyny parowej, po kilkunastu latach pogląd ten bardzo się zmienił.

Pod koniec lat dwudziestych XIX wieku wybudowano pierwsze odcinki kolei w Wielkiej Brytanii, USA, Francji i Austrii, choć jeszcze w wielu przypadkach nadal jako siły pociągowej używano zwierząt (konie). W trzeciej dekadzie wieku powstały pierwsze drogi żelazne w: Belgii, Bawarii, Saksonii, Prusach, Rosji, Neapolu, Badenii, Nassau i na Kubie. W dekadzie czwartej w: Królestwie Hanoweru, Toskanii, Wirtembergii, Holandii, Sardynii, Hiszpanii, Danii, Szwajcarii, Szwecji i Norwegii. Dopiero w połowie wieku XIX oddano pierwsze odcinki kolei w Portugalii i Państwie Kościelnym ${ }^{4}$.

Pierwszym połączeniem kolejowym na obszarze państw niemieckich, z zastosowaniem parowozu, była wybudowana w 1835 roku linia kolejowa w Bawarii: Norymberga - Fürth.

${ }^{4}$ J. Myszczyszyn, Koleje żelazne, jako istotny element procesu wstępnej industrializacji państw niemieckich, „Kultura i Historia” 2010, nr 17 - http://www.kulturaihistoria.umcs.lublin.pl/archi ves/1757 (dostęp: 1 III 2014). 
Pierwszą linię kolejową zbudowaną w północnej części Niemiec (Prusy) był odcinek oddany 29 października 1838 roku Berlin-Poczdam. Do końca 1839 roku w Niemczech było w użyciu (z włączeniem linii obsługiwanych przy udziale koni) nie więcej niż 86,5 mili, w Anglii 260 mil, w USA 476 mil $^{5}$.

Wobec szybkiego tempa rozwoju linii kolejowych w Europie Zachodniej i USA znany ekonomista, twórca niemieckiej szkoły historycznej Friedrich List, już w 1833 roku, w swoim memorandum Über ein sächsisches Eisenbahn-System als Grundlage eines allgemeinen deutschen Eisenbahn-Systems, und insbesondere über die Anlegung einer Eisenbahn von Leipzig nach Dresden propagował plan rozwoju kolei, jako nowego środka transportu, który obok szybszego, pewniejszego przemieszczania osób i towarów byłby dźwignią rozwoju kraju i postępu cywilizacyjnego ${ }^{6}$. Na poniższym rysunku (rys. 1) zobrazowano plan sieci kolejowej na obszarze państw niemieckich autorstwa F. Lista. Już w tym czasie zauważalne jest znaczenie miasta Szczecin, jako zaplecza Berlina, z planem linii kolejowej pomiędzy miastami. Pozostałe rejony Pomorza pozostawały bez połączeń kolejowych.

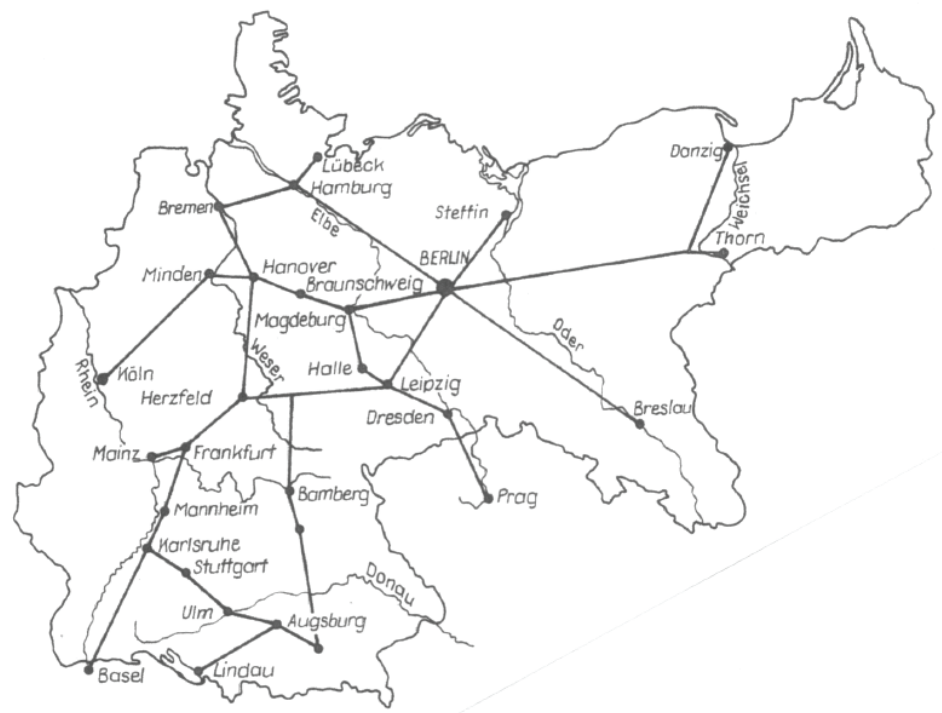

Rys. 1. Niemiecka sieć kolei żelaznych według planów F. Lista (1833 r.).

Źródło: F. List, Über ein sächsisches Eisenbahn-System als Grundlage eines allgemeinen deutschen Eisenbahn-Systemes, und insbesondere über die Anlegung einer Eisenbahn von Leipzig nach Dresden, Leipzig 1833.

${ }^{5}$ E. Behm, $d z$. cyt., s. 28.

${ }^{6}$ F. List, Über ein sächsisches Eisenbahn-System als Grundlage eines allgemeinen deutschen Eisenbahn-Systemes, und insbesondere über die Anlegung einer Eisenbahn von Leipzig nach Dresden, Leipzig1833; M. Hölzinger, Strategische Bedeutung von Lobbyarbeit im Spiegel der historischen Entwicklung der verkehrspolitischen Rahmenbedingungen in Deutschland: Handlungsmöglichkeiten für das Lobbying im Unternehmensinteresse der DB AG im Politikfeld Raumordnung, Trier 2002, s. 36. 
W propagowaniu swoich planów rozbudowy kolei F. List wykorzystał praktyczną wiedzę wyniesioną ze swojego pobytu w USA. W swoim dziele wielokrotnie nawiązuje do warunków i kosztów budowy linii kolejowych za oceanem.

Wracając do rozwoju kolejnictwa w Prusach należy podkreślić, że był on skorelowany z rozwojem przemysłu ciężkiego, w tym górnictwa. Niemałe znaczenie miały reformy społeczno-polityczne przeprowadzone w Prusach po upadku Napoleona I Bonaparte. Jedną z nich, odwleczoną w czasie, było uwłaszczenie chłopów (edykty z lat 1807, 1811, 1816, 1821, 1827, 1850 i 1857). Chłopi otrzymali ziemię na własność i zniesione zostały powinności feudalne. Reforma agrarna umocniła pozycję bogatego ziemiaństwa (junkrów pruskich). Przejęli oni ok. 1/3 ziemi chłopskiej, odgrywając ważną rolę w eksporcie zbóż, a także współdecydując o planach i realizacji polityki gospodarczej rządu?

Zmieniono ustrój najwyższych władz państwowych (utworzono rząd na czele z kanclerzem), rozpoczęto reorganizację administracji i wprowadzono nowy system podatkowy ${ }^{8}$. Powyższe reformy zapoczątkowały tzw. pruską drogę do kapitalizmu.

Punktem zwrotnym dla rozwoju transportu była z pewnością pruska ustawa handlowa i celna z maja 1818 roku (das preußische Handels- und Zollgesetz), na mocy której zniesiono cła pomiędzy prowincjami pruskimi. Był to pierwszy etap unifikacji celnej. Prusy stworzyły na swym terytorium, obejmującym znaczną część terytorium Niemiec, jednolity rynek. Kolejne próby zniesienia granic celnych na obszarze państw niemieckich zaowocowały powstaniem ważnej instytucji dla tworzenia jedności gospodarczej i politycznej państwa niemieckiego - Niemieckiego Związku Celnego (1834) ${ }^{9}$.

Dzięki zniesieniu wewnętrznych granic celnych pomiędzy państwami Związku wzrastały obroty handlowe, ale i konieczny stawał się rozwój sprawnego transportu na większe odległości. Jednak dążenia w tym zakresie dotyczące postępowych kół zarówno burżuazji, jak i mieszczaństwa pruskiego, były skutecznie hamowane przez konserwatywne koła junkierskie ${ }^{10}$.

C. Matschoss podsumowując w swojej książce stulecie niemieckiego przemysłu maszynowego w rozdziale III pt. Von Beginn des Eisenbahnzeitalters bis zur Gründung des Deutschen Reiches dowodzi, że Friedrich Harkort już w 1825 roku budował na masową skalę drogi żelazne. Szyn używano od dawna w kopalniach, a wagony do których zaprzężone były konie, służyły do transportu urobku węgla.

\footnotetext{
${ }^{7}$ W. Grabska, Ekonomiczna ekspansja Niemiec na Wschód w latach 1870-1939, Wrocław-Warszawa-Kraków 1964, s. 8 i n.

${ }^{8}$ W. Czapliński, A. Galos, W. Korta, Historia Niemiec, Wrocław-Warszawa-Kraków-Gdańsk 1981, s. 460-464.

${ }^{9}$ J. Myszczyszyn, Znaczenie Niemieckiego Związu Celnego w budowie jedności gospodarczej Niemiec, „Kultura i Historia” 2010, nr 18.

${ }^{10}$ S. Koziarski, Sieć kolejowa Polski, Opole1993, s. 7.
} 
Mimo nacisku na rząd, aby siłę mięśni zwierząt zastąpić zastosowaniem maszyny parowej, F. Harkort nie wskórał wiele, gdyż i przedstawiciele rządu uważali, że potrzeby komunikacyjne są zabezpieczone poprzez istniejące tradycyjne drogi lądowe i wodną sieć śródlądową. Bardzo sceptycznie do rozbudowy dróg żelaznych podchodzili również obywatele, właściciele kopalń, nie tylko nie dostrzegali korzyści, ale uważali, że nowy środek lokomocji może przyczynić się jedynie do powiększania strat ${ }^{11}$.

Dla powstania sieci dróg kolejowych z formalnego względu potrzebne były regulacje prawne dotyczące m.in.: inwestora (w tym prywatnych firm, spółek), przyznawania prawa do budowy i użytkowania kolei, specjalnych zezwoleń (koncesje) dla samego otwarcia zakładu (spółki). W latach trzydziestych XIX wieku w Prusach powstawały nowe prywatne towarzystwa kolejowe, spekulowano kursami akcji, a rynek oczekiwał stosowanego ustawodawstwa. W 1838 roku zgromadzony przez kolejowy sektor prywatny kapitał akcyjny wyniósł 1,4 mln talarów (Thr). Państwo pruskie natomiast starało się umiejętnie kontrolować prywatne przedsięwzięcia, aby w przyszłości dążyć do nacjonalizacji. Wyrazem tego była Ustawa o kolejach (Das Königlich Preußische Eisenbahngesetz), wydana 3 listopada 1838 roku. Ustawa dokładnie precyzowała rejestrację, przyznawanie koncesji, kontrolę państwa nad spółkami kolejowymi. Mimo tego, że nie dała oczekiwanych przywilejów dotyczących m.in. użytkowania gruntów, podziału zysków, niezależności względem państwa i w wielu kołach spotkała się z dużym rozczarowaniem była ważnym wydarzeniem i impulsem dla dalszego rozwoju sieci dróg żelaznych w Prusach.

Dla przykładu $§ 22$ Ustawy precyzował, że zbudowana linia kolejowa nie może być wcześniej otwarta niż po sprawdzeniu instalacji i wydaniu stosowanego zezwolenia przez rząd ${ }^{12}$. Zgodnie z $\S 42$ p. 1. państwo po 30 latach funkcjonowania kolei (prywatnej) zastrzegało sobie wykup linii na warunkach określonych w ustępie a) ${ }^{13}$. Jak zauważa S. Koziarski - powyższa Ustawa wpłynęła na chwilowy nastrój rozczarowania.

Stąd też pierwszy okres budowy kolei żelaznych w Prusach to praktycznie schyłek lat trzydziestych - początek lat czterdziestych XIX wieku z zastrzeżeniem, że to głównie sektor prywatny angażował się w powstanie i rozbudowę pruskiej sieci kolejowej.

Rysunek 2 obrazuje ogółem długość linii kolejowych dla Królestwa Prus w latach 1838-1870 z określeniem długości linii kolejowych będących w rękach sektora prywatnego.

${ }^{11}$ C. Matschoss, Ein Jahrhundert deutscher Maschinenbau: von der Mechanischen Werkstätte bis zur Deutschen Maschinenfabrik 1819-1919, Berlin 1919, s. 47-48 i n. Straty z kolejnictwa miały dotyczyć np. dużego hałasu, pozbawiania pracy woźniców, pracowników fizycznych.

${ }^{12}$ Das Königlich Preußische Eisenbahngesetz vom 3. November 1838, Elberfeld, s. 8.

${ }^{13}$ Tamże, s. 13 - wykup w cenie 25-krotnej wypłacanej przez spółkę przeciętnej kwocie dywidendy $\mathrm{z}$ ostatnich 5 lat. 


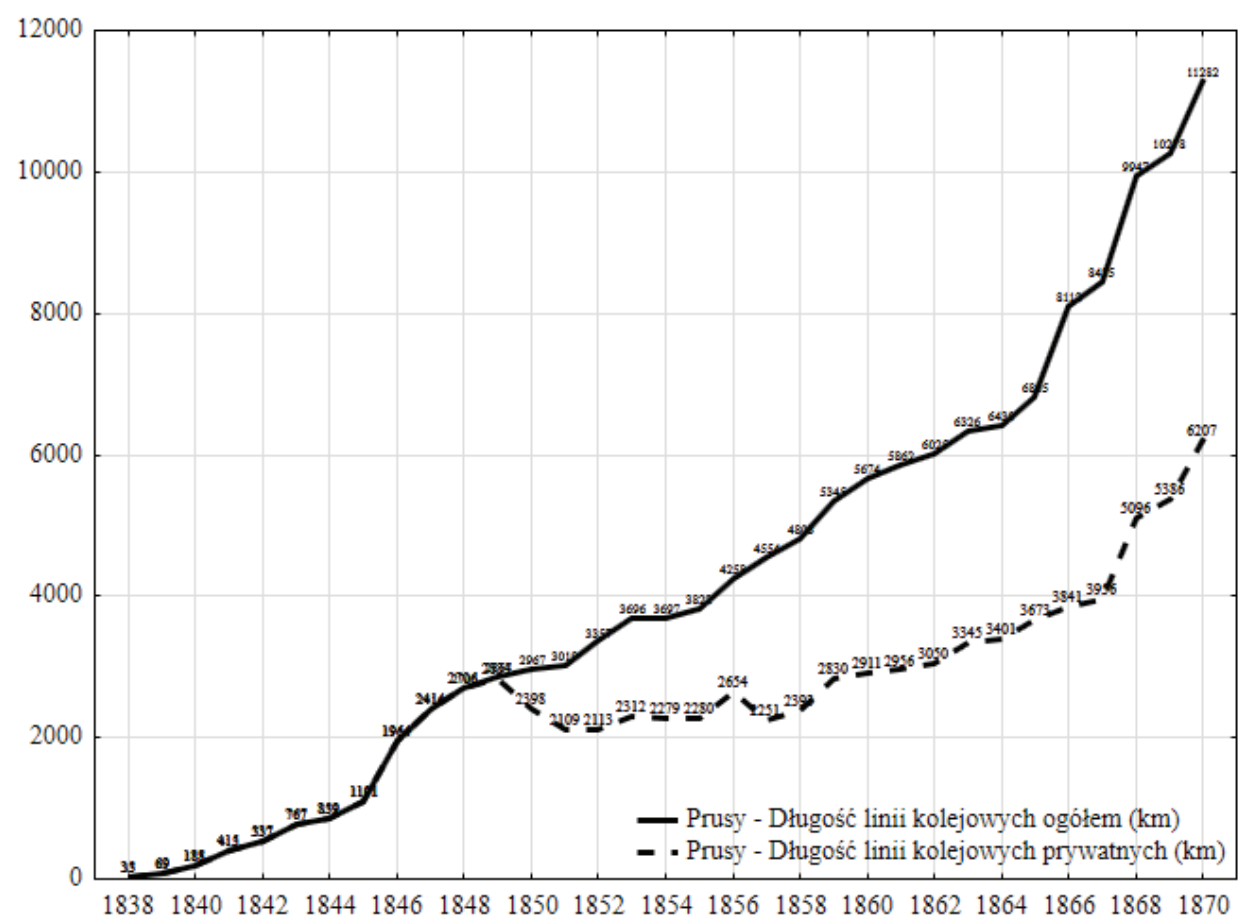

Rys. 2. Długość linii kolejowych w Prusach w latach 1838-1870 z określeniem długości szlaków kolejowych należących do sektora prywatnego $(\mathrm{km})$.

Źródło: Opracowanie własne na podstawie: H. Schwabe, Geschichtlicher Rückblick auf die ersten 50 Jahre des preussischen Eisenbahnwesens, Berlin 1895, s. 109-112.

Praktycznie do końca lat czterdziestych XIX wieku, czyli pierwsze dziesięciolecie rozbudowy szlaków kolejowych w Prusach, możliwe było dzięki zaangażowaniu sektora prywatnego. Do 1848 roku zbudowano łącznie 2706 km linii kolejowych, zaś dopiero w 1849 roku państwo pruskie rozpoczęło bardziej aktywne próby budowy państwowych szlaków kolejowych.

Duża aktywność prywatnych spółek kolejowych zauważalna była do końca lat czterdziestych; po 1848 roku odnotować należy pewny zastój, od połowy lat pięćdziesiątych następuje ponownie ożywienie w rozbudowie szlaków kolejowych. Ma to związek z zaangażowaniem państwa w inwestycje. W rezultacie na początku lat sześćdziesiątych państwo wybudowało blisko $1500 \mathrm{~km}$ dróg, w tym zarządzało blisko 1270 km szlaków prywatnych, co dawało udział sektora publicznego w ponad $26 \%$ całości powstałych dróg żelaznych.

W latach 1840-1848 średnie roczne tempo przyrostu długości szlaków prywatnych wynosiło 31,5\%; aby w latach 1848-1855 spaść do 2,36\% rocznie, w kolej- 
nym okresie (1855-1862) wyniosło 4,18\% rocznie. Z kolei tempo przyrostu sieci państwowych dróg kolejowych w latach 1848-1850 wyniosło 4,6\% rocznie, aby w latach 1855-1862 zanotować wzrost do 5,87\%.

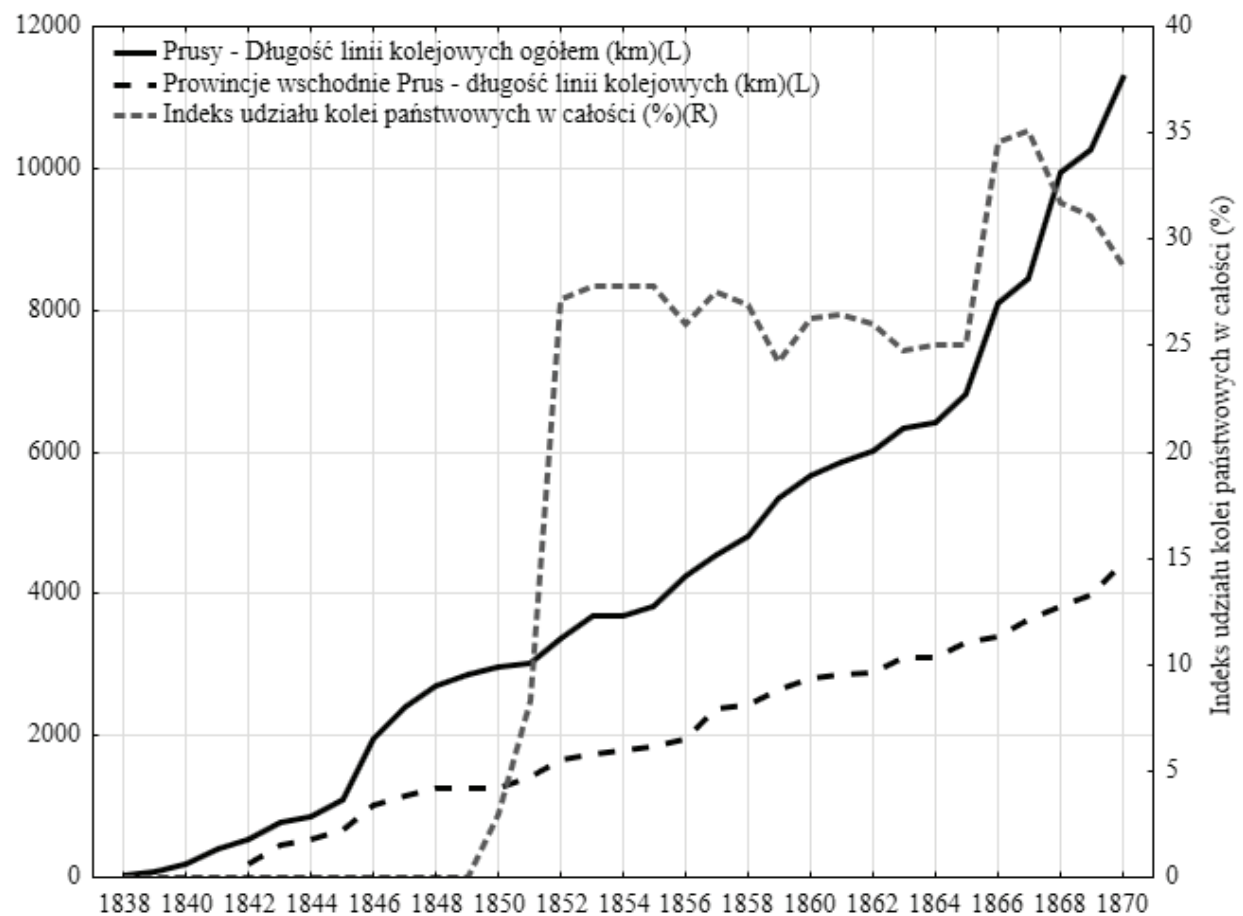

Rys. 3. Długość linii kolejowych w Prusach w latach 1838-1870 (km) z uwzględnieniem prowincji wschodnich i określeniem udziału kolei państwowych (\%).

Źródło: Opracowanie własne na podstawie: H. Schwabe, Geschichtlicher Rückblick auf die ersten 50 Jahre des preussischen Eisenbahnwesens, Berlin 1895, s. 109-112, S. Koziarski, Sieć kolejowa Polski, Opole 1993.

Na rysunku 3 ukazano długość linii kolejowych w Prusach na tle długości linii w prowincjach wschodnich $\mathrm{z}$ określeniem procentowego udziału kolei państwowych.

\section{Prowincja Pomorze - zmiany gospodarcze w połowie XIX wieku, dominacja Szczecina}

Prowincja Pomorze po kongresie wiedeńskim była jedną z prowincji Królestwa Prus, a po zjednoczeniu w 1871 roku, Cesarstwa Niemieckiego.

W połowie XIX wieku prowincja leżała pomiędzy $52^{\circ} 58^{\prime}$ a $54^{\circ} 50^{\prime}$ północnej szerokości i pomiędzy 30 7' a 35 43' wschodniej długości geograficznej. Położona 
nad Morzem Bałtyckim po obu stronach Odry. Rzeka dzięki rozbudowie kanałów była połączona drogą wodną już w połowie XIX wieku z Wisłą i Elbą (Łabą).

Odra dzieliła prowincję na dwie nierówne części: Przedpomorze (Vorpommern) z wyspami Uznam, Wolin i Rugią oraz Pomorze Tylne (Hinterpommern) - kraj na prawym brzegu Odry. W 1816 roku dla prowincji ustanowiono trzy okręgi (Regierungsbezirke) z siedzibą w Szczecinie, Koszalinie (Pomorze Tylne) i w Strzałowie (Straslund) (Przedpomorze). Okręg szczeciński składał się z 12 powiatów (Kreisen), koszaliński z 10, zaś strzałowski z 4.

Położenie prowincji było bardzo sprzyjające dla rozwoju handlu zarówno morskiego jak i śródlądowego, a tym samym znaczenia prowincji w rozwoju handlu światowego. Prowincja była położona centralnie w państwie pruskim i liczyła $30131,40 \mathrm{~km}^{2}$, co stanowiło 8,6\% powierzchni Królestwa Prus i 5,6\% utworzonego w 1871 roku Cesarstwa. Liczba ludności w 1910 roku stanowiła zaledwie 4,5\% liczby mieszkańców Królestwa Prus i 2,6\% całej Rzeszy.

Stolicą prowincji był Szczecin, liczący w 1825 roku 25,5 tys. mieszkańców, w 1847 roku - 43,5 tys. mieszkańców, 1871 roku - 72,2 tys. mieszkańców, w 1900 roku miasto przekroczyło 210,7 tys. mieszkańców, zaś 1 grudnia 1910 roku już 236113 mieszkańców $^{14}$.

W 1855 roku prowincja liczyła 1,27 mln mieszkańców, w tym 630,54 tys. męż$\operatorname{czyzn}^{15}$. W połowie wieku liczyła 72 miasta i ponad 7 tys. wsi, kolonii, majątków, leśniczówek itd.

Średnie tempo przyrostu liczby ludności w latach 1885-1890 wyniosło $+1,02 \%$, w latach $1890-1895+3,5 \%$, w latach $1895-1900+3,86 \%$, zaś w okresie 1867-1900 liczba ludności wzrosła o ponad 13\%, wynosząc 1,63 mln osób. Wzrost liczby ludności dla Prowincji Pomorze był poniżej średniej w stosunku do wszystkich prowincji pruskich (np. w tym czasie przyrost w pruskiej prowincji Nadrenia wyniósł niemal 67\%).

W połowie XIX wieku mieszkańcy prowincji głównie zajmowali się uprawą roli, chowem zwierząt, rybołówstwem, żeglugą (przewozy), handlem, służbą wojskową. Najbardziej dynamicznie rozwijał się przemysł spożywczy (cukrownictwo, gorzelnictwo, młynarstwo). Przemysł metalowo-maszynowy skupiał się głównie w Szczecinie. Już w latach pięćdziesiątych w prowincji rozwijał się przemysł maszynowo-stoczniowy, cementowy, chemiczny. W prowincji ulokowany był jeden uniwersytet, 9 gimnazjów i jedna szkoła pedagogiczna. Minimalny

${ }^{14}$ J. Myszczyszyn, Protekcjonizm agrarny jako czynnik utrudniajacy rozwój przemystu w Prusach w końcu XIX w. i początkach XX w. na przyktadzie prowincji Pomorze, [w:] Z dziejów przemystu przed 1945 rokiem, red. J. Chumiński, M. Zawadka, Wrocław 2012 s. 59-60.

${ }^{15}$ Jahrbuch der Provinz Pommern, Zehnete Aus., Verlag von Th. von Nahner, Stettin 1857, s. 6; D. Mellies, Modernisierung in der preußischen Provinz?: Der Regierungsbezirk Stettin im 19. Jahrhundert, Kritische Studien zur Geschichtswissenschaft, Göttingen 2012. 
wpływ na rozwój gospodarczy prowincji miał pomorski sejmik prowincjonalny, a sejmiki miejskie były zdominowane przez większe miasta.

Reformy uwłaszczeniowe zapoczątkowane na początku XIX wieku przez Prusy doprowadziły do tego, że około 1838 roku na terenie Pomorza Zachodniego ponad $90 \%$ gospodarstw uzyskało ziemię na własność ${ }^{16}$. W kolejnych latach daje się zauważyć udział ziemiaństwa pruskiego w zagarnianiu własności chłopskiej. Reformy agrarne utrwaliły ekonomiczną dominację junkierstwa na wsi.

W 1853 roku w strukturze własności gruntów rolnych daje się zauważyć znaczny udział dużych gospodarstw o powierzchni powyżej 600 mórg magdeburskich (ok. 152 ha). Łącznie takich gospodarstw było 2516, a powierzchnia całkowita wyniosła 6,4 mln mórg (około 1,62 $\mathrm{mln}$ ha), co stanowiło blisko 61\% całości gruntów prowincji ${ }^{17}$.

Spośród niemal $21 \mathrm{mln}$ ha ziemi rolnej w Prusach w 1907 roku ponad 28,1\% (5,9 mln ha) należało do gospodarstw liczących ponad 100 ha, gospodarstwa o powierzchni $50-100$ ha stanowiły najliczniejszą grupę tj. 31,3\% (około 6,6 mln ha). Zupełnie inna struktura ziemi rolniczej była w prowincji Pomorze.

Zdecydowanie najliczniejszą grupą były gospodarstwa karłowate o powierzchni poniżej 0,5 ha, które stanowiły w Prusach 35,4\% na Pomorzu 35,8\%. Działki o powierzchni do 2 ha stanowiły $23,2 \%$. W grupie od 5 ha do 100 ha tzw. małych i dużych gospodarstw chłopskich na Pomorzu było 28,4\%. Na 1000 gospodarstw tych o powierzchni 100 ha i powyżej było w Prusach 6, na Pomorzu 15. Największa koncentracja wielkiej własności miała miejsce w regencji strzałkowskiej, najmniejsza w regencji szczecińskiej.

Analizując strukturę upraw w prowincji Pomorze łatwo zauważyć, że w uprawach dominowały zboża i rośliny strączkowe (blisko 62,5\%), rośliny okopowe $18,6 \%$ oraz rośliny pastewne ${ }^{18}$.

Państwo pruskie w latach 1831-1840 wspierało rozbudowę małych portów Pomorza Zachodniego (np. Kołobrzeg, Darłowo, Ustka). Spotkać się można z tezą, że junkrzy byli zainteresowani rozbudową portów, dzięki którym mogli eksportować produkty rolne, szczególnie w okresie dominacji wolnej wymiany handlowej. Państwo i władze lokalne angażowały się w budowę sieci kolejek wąskotorowych. Sieć ta była najlepiej rozwinięta na Pomorzu Zachodnim.

Według danych z 1910 roku w prowincji Pomorze funkcjonowało 269 przedsiębiorstw, w tym 125 w Szczecinie, o łącznym kapitale 54,15 mln marek (M).

${ }^{16}$ E. Włodarczyk, Główne linie dziejów Pomorza Zachodniego w latach 1815-1945 r., Szczecin 2001, s. 13.

${ }^{17}$ Jahrbuch der Provinz Pommern..., s. 44.

${ }^{18}$ W. Achilles, Die Landwirtschaft in Preussen in den Grenzen des wissenschaftlichen Erkenntnisstandes und der Ausbildung vor dem Ersten Weltkrieg, [w:] Wirtschaft, Wissenschaft und Bildung in Preußen, red. K. Kaufhold, B. Sösemann, Stuttgart 1998, s. 40. 
Najwięcej przedsiębiorstw liczyły branże: handel (59), przemysł spożywczy (43), kopalnictwo/kamieniarstwo (36), transport (27), przemysł maszynowy (25). W prowincji w 1913 roku zarejestrowanych było 105 spółek akcyjnych o kapitale blisko $192 \mathrm{mln}$ M. Liczebnie stanowiło to 3,58\% wszystkich spółek akcyjnych w Prusach, kapitałowo jedynie 1,45\%. Dominujące branże to transport, przemysł spożywczy, przemysł maszynowy, kamieniarski.

Niestety wiele mniejszych ośrodków miejskich w prowincji na przełomie XIX i XX wieku przeżywało okres stagnacji i regresu, z wielu miast zniknęły grupy kupców hurtowych, bankierów, upadł przemysł sukienniczy.

Szczecin, stolica prowincji, dzięki swojemu położeniu i rozwojowi dróg wodnych i klejowych była już na początku XX wieku świetnie połączony ze stolicą Prus - Berlinem, a także Wrocławiem, Hamburgiem, Gdańskiem, Królewcem (koleje), portami Morza Północnego i Śródziemnego (połączenie morskie), a także rozbudowywano wodne połączenia śródlądowe (rozbudowa kanałów) ${ }^{19}$. Szczecin, jak podaje E. Włodarczyk, wkroczył dużo wcześniej od Poznania i Gdańska $\mathrm{w}$ fazę industrializacji ${ }^{20}$.

\section{Rozwój sieci kolejowej w Prowincji Pomorze za szczególnym uwzględnieniem spółki Berlin-Stettiner Eisenbahn}

Tempo rozwoju infrastruktury komunikacyjnej, w tym krajowej sieci dróg bitych w Prusach w połowie XIX wieku (i wcześniej), należy ocenić negatywnie. Państwo pruskie w tym względzie pozostawało zacofane. Jak podaje D. Melies, w początkach XIX wieku Prusy na tle Anglii, Francji, monarchii Habsburgów, w których rozbudowywano drogi bite, ciągle używały wątpliwej jakości dróg lokalnych ${ }^{21}$. Trudno dziwić się, że kolej była szansą na polepszenie komunikacji w rozległym państwie (włączając Niemiecki Związek Celny).

Pierwsze projekty budowy kolei na obecnych ziemiach polskich (pod zaborem pruskim) miały miejsce na Śląsku. Była to prowincja mocno uprzemysłowiona, obok części zachodnich Prus (Westfalii), w których dokonywał się proces industrializacji. Prowincje wschodnie (Pomorze, Prusy Zachodnie, Prusy Wschodnie, Prowincja Poznań) ze względu na słabe tempo rozwoju gospodarczego, brak rozwiniętego przemysłu wydobywczego, zajmowały się głównie rolnictwem. Kolejne reformy w zakresie uwłaszczenia przyczyniły się do wzmocnienia pozycji posiadaczy ziemskich, prowadząc jednocześnie do pauperyzacji ludności bezrolnej.

\footnotetext{
${ }^{19}$ Pommern Jahrbuch, Stettin 1928, s. 138-139.

${ }^{20}$ E. Włodarczyk, Wielki przemyst Szczecina w latach 1850-1914, Warszawa 1982.

${ }^{21}$ D. Mellies, Modernisierung in der preußischen Provinz?: Der Regierungsbezirk Stettin im 19. Jahrhundert, „Kritische Studien zur Geschichtswissenschaft”, Bd. 201, Göttingen, s. 139 i n. Na 14989 km (1848 r.) bitych dróg w Prusach na Pomorzu wybudowano łącznie 87,86 km (udział $0,59 \%)$.
} 
Mimo swojego głównie rolniczego charakteru Prowincja Pomorze przodowała w początkowej fazie rozwoju sieci kolejowej w Prusach. Głównym czynnikiem mającym wpływ na plany rozbudowy kolei w prowincji miał port w Szczecinie. Niewielka odległość portu szczecińskiego od Berlina sprawiła, że stolica prowincji szybko stał się zapleczem portowym dla stolicy Prus. Stolica Pomorza, poza tym w odróżnieniu od pozostałych miejscowości, miała także rozległe interesy handlowe wybiegające poza samą prowincję, m.in. Wielkopolskę, Śląsk, Królestwo Polskie. Jak zresztą podaje S. Koziarski, pierwsze projekty linii kolejowej na Pomorzu Zachodnim, łączącej Berlin ze Szczecinem sięgają już połowy lat trzydziestych XIX wieku' ${ }^{22}$.

Komitet budowy kolei Berlin-Szczecin powstał już w 1835 roku, a inicjatorem przedsięwzięcia był A. Altvater. Nie bez problemów zebrano niezbędny kapitał i uzyskano koncesję. Wśród członków komitetu towarzystwa byli junkrzy, którzy zasiadali w sejmiku. W skład dyrekcji wchodzili m.in.: nadburmistrz Szczecina, kupcy szczecińscy, urzędnicy, bankierzy z Berlina ${ }^{23}$. W budowę kolei zaangażował się także nadprezydent Szczecina Wilhelm von Bonin, co podkreślało wagę przedsięwzięcia. Nadprezydent był zadania, że tanie koleje powinny być budowane przez państwo przy aktywnym współudziale prowincji ${ }^{24}$. Do realizacji budowy kolei przystąpiono już 3 sierpnia 1840 roku. Budową kierował inspektor dróg G. H. Neuhaus ${ }^{25}$. Koncesję na budowę uzyskała prywatna spółka Berlin-Stettiner-Eisenbahn (BSE). Kapitał akcyjny spółki wynosił w 1843 roku $3788761 \mathrm{Thr}$. i wzrósł w roku 1850 do 5950454 Thr., aby w 1861 roku wynieść 9170703 Thr. ${ }^{26}$

Pierwszy odcinek kolei z Berlina do Eberswalde oddano do użytku w dwa lata później. Całą linię kolejową łączącą Berlin ze Szczecinem oddano 15 sierpnia 1843 roku. Długość szlaku kolejowego wyniosła 17,753 mili niemieckiej (około $135 \mathrm{~km})^{27}$. W początkowym okresie kursowały w trakcie dnia dwie pary pociągów, ze średnią prędkością 35-40 km/h. Podróż ze Szczecina do Berlina trwała około $4,5 \mathrm{~h}$.

W 1843 roku Spółka przystąpiła do przedłużenia szlaku ze Szczecina do Stargardu Szczecińskiego. I po raz kolejny okazało się, że zebranie funduszy jest wielkim problemem - brak gwarancji ze strony sejmiku komunalnego zmusił spółkę BSE do emisji obligacji na 4\%, które przejęło państwo. Linię o długości 4,576 mili (około 34,5 km) oddano do użytku 1 maja 1846 roku. Linię przedłużono ze

${ }^{22}$ S. Koziarski, $d z$. cyt., s. 43.

${ }^{23}$ A. Mielcarek, Transport drogowy, wodny i kolejowy $w$ gospodarce prowincji pomorskiej w latach 1815-1914, Szczecin 2000, s. 73-75.

${ }^{24}$ Tamże, s. 75.

${ }^{25}$ F. Ten, Eisenbahnen und Eisenbahnunternehmer in der Industriellen Revolution. Ein preussisch/deutsch-englischer Vergleich, „Kritische Studien zur Geschichwissenschaft”, Bd. 120, Göttingen 1997, s. 451.

${ }^{26}$ Jarbuch für die amtlische Statistik des Preussischen Staats, Berlin 1863, s. 513.

${ }^{27}$ O. Hübner, dz. cyt., s. 226. 
Stargardu przez Krzyż do Poznania, a w 1856 roku uruchomiono połączenie ze Śląska do Szczecina (budowała już inna spółka kolejowa).

Równie ważne dla określenia celów gospodarczych są uzyskane wyniki w przewozach kolejowych. Na rysunku (rys. 4) zobrazowano wielkość przewozów osobowych oraz towarowych na odcinku Berlin-Stargard. I tak w początkach istnienia połączenia przewieziono rocznie ponad 272 tys. osób (1844), w 1850 roku 263518 osób, w 1857 roku liczba wzrosła do ponad 380 tys. osób, zaś w 1862 roku na dwóch liniach Berlin-Szczecin-Stargard, Stargard-Koszalin-Kołobrzeg liczba przewiezionych pasażerów wzrosła do ponad 813 tys. osób, w dwa lata później do 871 tys. osób.

W 1862 roku na odcinku Berlin-Szczecin-Stargard przetransportowano 604439 osób, w tym 4355 w I klasie, 111152 w II klasie, 459733 osób w III klasie ${ }^{28}$, na odcinku Stargard-Koszalin-Kołobrzeg przewieziono z kolei 208687 osób, w tym 512 w I klasie, 32692 osób w II klasie, 129938 w III klasie, 33211 w IV klasie. Spółka z tytułu przewozów pasażerskich uzyskała: 551831 Thr. przychodów (Berlin-Szczecin-Stargard) i 154593 Thr. (Stargard-KoszalinKołobrzeg).

$\mathrm{Na}$ odcinku Berlin-Szczecin-Stargard-Koszalin-Kołobrzeg przewożono głównie: zboże, śledzie, rośliny strączkowe, cynk, drewno budowlane, spirytus, ziemniaki, drewno opałowe, produkty młynarskie. Transport towarowy wzrósł z blisko 39 tys. $\mathrm{Mg} \mathrm{w} 1844$ roku do blisko 442 tys. Mg w 1862 roku, aby w 1871 roku przekroczyć 773 tys. Mg.

W latach 1847-1848 kolej przeżywała pierwszy kryzys, a przyczyną była duńska blokada portu w Szczecinie. Spośród 8835103 przewiezionych cetnarów (1862) ponad 7,3 mln dotyczyło linii Berlin-Szczecin-Stragard. W 1862 roku Spółka osiągnęła 692220 Thr. przychodów z tytułu przewozu towarów na odcinku Berlin-Szczecin-Stargard i 146816 Thr. na odcinku Stargard-Koszalin-Kołobrzeg.

W sumie w 1862 roku Kolej Szczecińsko-Berlińska zanotowała 1583069 Thr. przychodów (ponad $80 \%$ przychodów odcinek Berlin-Szczecin-Stargard). Na odcinku Berlin-Szczecin-Stargard w przychodach ponad 54,5\% stanowił przychód z transportu towarów; dla linii Stargard-Koszalin-Kołobrzeg stosunek ten wynosił około 46,7\%. Na 1 milę przychody dla linii Berlin-Szczecin-Stargard wyniosły 56399 Thr. (7488 Thr./km) a dla odcinka Stargard-Koszalin-Kołobrzeg zaledwie $13801 \mathrm{Thr}$ (1832 Thr./km).

Wydatki łącznie wyniosły: na odcinku odcinek Berlin-Szczecin-Stargard 656424 Thr., zaś na odcinku Stargard-Koszalin-Kołobrzeg 314663 Thr., co odpowiednio oznaczało $3875 \mathrm{Thr} . / \mathrm{km}$ i $1832 \mathrm{Thr} / \mathrm{km}$. Wydatki stanowiły $51,7 \%$ przychodów na odcinku Berlin-Szczecin-Stargard i 100\% przychodów na odcinku Stargard-Koszalin-Kołobrzeg. W przypadku linii Berlin-Szczecin-

\footnotetext{
${ }^{28}$ IV klasy dla połączeń osobowych nie było w tym czasie.
} 
Stargard Spółka osiągnęła nadwyżkę w wysokości 611982 Thr. (3 612 Thr./1km). Osiągnięta nadwyżka przychodów nad kosztami w stosunku do zgromadzonego przez Spółkę kapitału wynosiła 8,24\%.

Spółka na odcinku Berlin-Szczecin-Stargard dysponowała 35 lokomotywami, zaś na odcinku Stargard-Koszalin-Kołobrzeg 28 parowozami i w sumie 634 wagonami towarowymi.

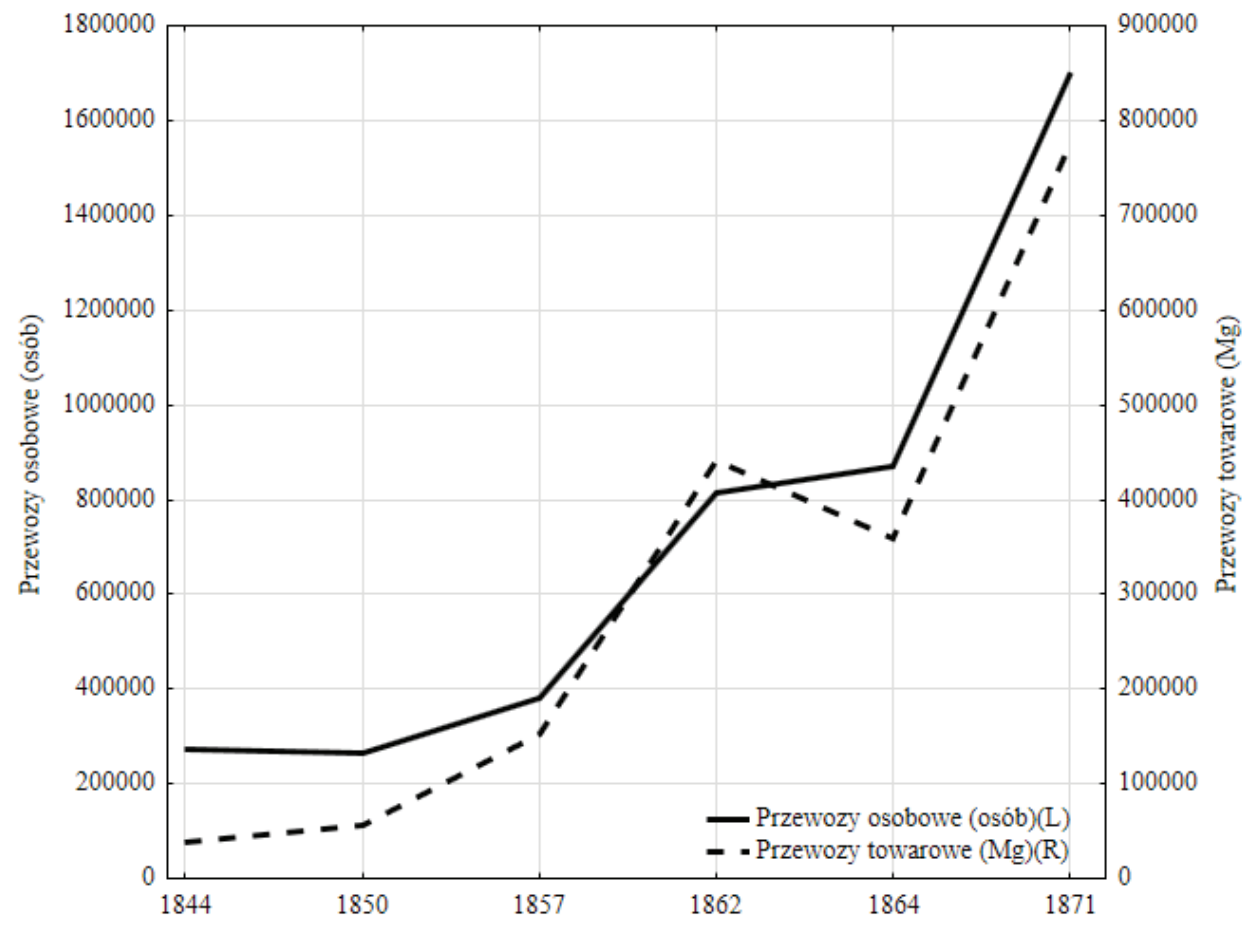

Rys. 4. Transport kolejowy pasażerski (osoby) i towarowy (Mg) na linii Berlin-Szczecin-Stargard Szczeciński (1844-1871).

Źródło: opracowanie wlane na podstawie: O. Wehde-Textor, Pommern und seine Eisenbahnen bis zum Anfang des zweiten Weltkrieges, Archiv für Eisenbahnwessen, Hf. 1, 1965; O. Hübner, Hübners Statistische Tabel aller Länder der Erde, Leipzig 1852; Deutsche Eisenbahn-Statistik für das Betriebs-Jahr 1862, Berlin 1864.

Ważnym dla całego regionu i prowincji Pomorze była rozbudowa sieci kolejowej w kierunku Poznania. O budowę linii zabiegali zarówno kupcy szczecińscy jak i berlińscy, widząc w Wielkopolsce zaplecze żywnościowe. Spółka akcyjna Stargadzko-Poznańska uzyskała w 1846 roku koncesję na budowę. Już w 1847 roku oddano do użytku odcinek Stargard-Dobiegniew $(66,5 \mathrm{~km})$, w 1848 roku Dobiegniew-Poznań $(105,7 \mathrm{~km})$. Po przejęciu linii przez Kolej Górnośląską (Oberschlesische Eisenbahn OSE) w 1856 roku uruchomiono połączenie Śląska ze Szczecinem. 
Innym wydarzeniem istotnym dla dalszego rozwoju sieci kolejowej na Pomorzu była decyzja o rozpoczęciu budowy przez Berlińsko-Szczecińską spółkę połączenia Stargard Szczeciński-Runowo Pomorskie-Lobez-Białogard-Koszalin. Budowę rozpoczęto w 1856 roku i oddano do użytku 1 czerwca 1859 roku. Długość szlaku Stargard-Koszalin-Kołobrzeg wyniosła 22,8 mili (około 172 km) ${ }^{29}$. Należy dodać, że w przypadku linii Stargard-Koszalin-Kołobrzeg kapitał w wysokości 3,5\% odsetek rocznie zapewniony był już przez rząd pruski.

W 1862 roku pod zarządem Spółki Berlińsko-Szczecińskiej było 45,12 mili kolei (około $340 \mathrm{~km}$ ). W przypadku Prowincji Pomorze 37,2 mili kolei (1862 r.) ciągle było dość znikomą długością w porównaniu do ponad 166 mil dróg krajowych, 143 mil dróg wojewódzkich i powiatowych, a także 73 mil żeglownych dróg wodnych ${ }^{30}$.

W latach sześćdziesiątych kolej Szczecińsko-Berlińska otrzymała koncesję na budowę odcinka Szczecin-Pasewalk (37 km). Linię otwarto w 1863 roku. Łącznie w 1867 roku Spółka wybudowała 82,27 mili linii kolejowej. W latach siedemdziesiątych Spółka wybudowała połączenia z portem w Świnoujściu (1876), wcześniej (1873) drugi tor na odcinku Angermünde-Szczecin-Stargard Szczeciński.

\section{Wzrost znaczenia sektora publicznego $w$ budowie kolei. Nacjonalizacja BSE Rozwój kolei wąskotorowych}

Pruski minister handlu i robót publicznych August von der Haydt dążył do podporządkowania kolei prywatnych państwu. Zadanie to ułatwiło udzielanie przez państwo w latach czterdziestych XIX wieku gwarancji wielu towarzystwom kolejowym, a także zapisy Ustawy z 1838 roku. Państwo np. przejęło kolej dolnośląską (1851), rok wcześniej przejęło zarząd nad odcinkiem Stargard-Poznań.

$\mathrm{W}$ drugiej połowie lat siedemdziesiątych państwo było zmuszone (głównie z powodów finansowych) przejąć i dokończyć część rozpoczętych budów. Do linii prywatnych budowanych na Pomorzu można zaliczyć odcinek WęgorzynoTczew, Berlin-Stralsund, Kostrzyn-Szczecin. W tym czasie państwo było szczególnie aktywne w nacjonalizacji kolei prywatnych, ale także w budowie nowych szlaków, inicjowało też budowę odcinków drugorzędnych.

Nacjonalizacja BSE odbyła się w dwóch odsłonach: upaństwowienie dwóch linii bocznych: Stargard-Koszalin-Kołobrzeg (1878), Angermünde-Stralsund (1878), upaństwowienie głównej linii BSE nastąpiło w latach 1879-1890.

W końcu lat sześćdziesiątych pojawił się pomysł budowy tanich linii o zasiągu lokalnym, państwo też przewidywało swój udział w budowie. Linie zaczęto rozbudowywać w latach osiemdziesiątych np. Dąbie-Kołobrzeg (1882), Piła-Wałcz (1881), Stargard-Kostrzyn (1882).

\footnotetext{
${ }^{29}$ Deutsche Eisenbahn-Statistik für das Betriebs-Jahr 1862, Berlin 1864, tab. 10-15.

${ }^{30}$ Jarbuch für die amtlische..., s. 500.
} 
W kolejnym okresie, czyli w latach dziewięćdziesiątych bardzo charakterystycznym dla prowincji Pomorze, rozpoczęto budowę linii trzeciego rzędu (zgodnie z wydaną ustawą w 1892 r. - Gesetz über Kleinbahnen und Privatanschlußbahnen vom 28.07.1892 tzw. „Kleinbahngesetz”). Zgodnie z $§ 1$ ww. ustawy koleje III rzędu ze względu na swój lokalny charakter i niewielkie znaczenie w powszechnym transporcie kolejowym nie podlegały restrykcjom ustawy z 3 listopada 1838 roku, np. zgodę na budowę i eksploatację wydawał prezydent rejencji. Efektem tej ustawy było powstanie pobocznych kolejek transportu publicznego pasażerskiego i towarowego.

Pionierem kolei wąskotorowych na Pomorzu bez wątpienia był Friedrich Lenz, urodzony w 1846 roku w Radle, powiat nowogardzki. Już w kilka dni po przyjęciu ustawy z 28 lipca 1892 roku założył przy udziale berlińskiego Handelsbanku spółkę Lenz\&Co GmbH z siedzibą w Szczecinie ${ }^{31}$.

W końcu I kwartału 1902 roku w prowincji Pomorze wybudowano już $1282,9 \mathrm{~km}$ linii (w tym $30 \mathrm{~km}$ to linie tramwajowe) i pod tym względem prowincja była zdecydowanym liderem na tle Królestwa Prus (łączna długość w tym czasie 9228 km). Łączny kapitał inwestycyjny wyniósł 44,4 mln M. (837 mln M. dla Prus). Przed wybuchem I wojny światowej (1913) zbudowano: $1717 \mathrm{~km}$ kolejek (po wyłączeniu linii tramwajowych 1669 km) ${ }^{32}$ na Pomorzu i $14065 \mathrm{~km}$ w Prusach (po wyłączeniu linii tramwajowych $10510 \mathrm{~km}$ ). Pomorskie koleje III rzędu stanowiły 15,8\% długości wszystkich tego rodzaju linii w Prusach. Łączny kapitał inwestycyjny wyniósł odpowiednio dla Pomorza $69 \mathrm{mln}$ M. (z tego 11,3 mln M. linie tramwajowe) i dla Prus 1,59 mld M. (z tego 919, 7 mln M. linie tramwajowe) $)^{33}$.

Linie kolei wąskotorowych w prowincji służyły przede wszystkim do transportu towarów, w tym płodów rolnych. Kolejki powstały w powiecie Franzburg (regencja stralsundzka), słupskim, kołobrzeskim, nowogardzkim, szadzkim, gryfickim, rugijskim, a także w innych np. szczecineckim, bytowskim, świdwińskim. Rozwój tych linii następował dzięki znacznemu wysiłkowi powiatów, prowincji, a także pomocy państwa i samorządów. Ze środków państwowych prowincja pomorska otrzymała na budowę kolejek blisko $28,3 \%$, prowincja przekazała $29,1 \%$, a same powiaty $42,7 \%$, do tego powiaty przekazywały środki finansowe na subwencję w wysokości niemal 600 tys. M. rocznie. Niemałe znaczenie w zakresie pozyskiwania funduszy odegrała współpraca władz prowincji, powiatów ze

\footnotetext{
${ }^{31}$ G. Kasten, Ein Rittergut im Wandel der Zeit. Erinnerungen an das pommersche Dorfleben und ad die Zeit bis 1957, Norderstedt 2009, s. 168.

${ }^{32} \mathrm{Z}$ włączeniem linii tramwajowych: w prowincji Pomorze: (48,5 km), w Prusach $3556 \mathrm{~km}$.

${ }_{33}$ Statistisches Jarbuch für den Preussische Staat, Königlischen Statistischen Buerau, Berlin 1904, s. 106; Statistisches Jarbuch für den Preussische Staat, Königlischen Statistischen Landesamt, Berlin 1915, s. 258. W roku 1913 kapitał inwestycyjny ulokowany w pruskich kolejach wyniósł ponad 19,2 mld M.
} 
spółką Lenz\&Co GmbH. Współpraca umożliwiła zarówno pozyskanie publicznych, ale także prywatnych źródeł finansowania, w czym rzeczywiście prowincja przodowała. Często okazywało się, że powiat uczestniczy jedynie w 1/3 części w budowie kolei, dla porównania w innych prowincjach było zupełnie inaczej ${ }^{34}$. Współpraca sektora publicznego (w tym samorządowego) prowincji z sektorem prywatnym umożliwiała utworzenie wielu połączeń komunikacyjnych, które ze względu na swój zasięg i potencjał miały znaczenie lokalne, ale wkomponowały się w krajobraz gospodarczy prowincji.

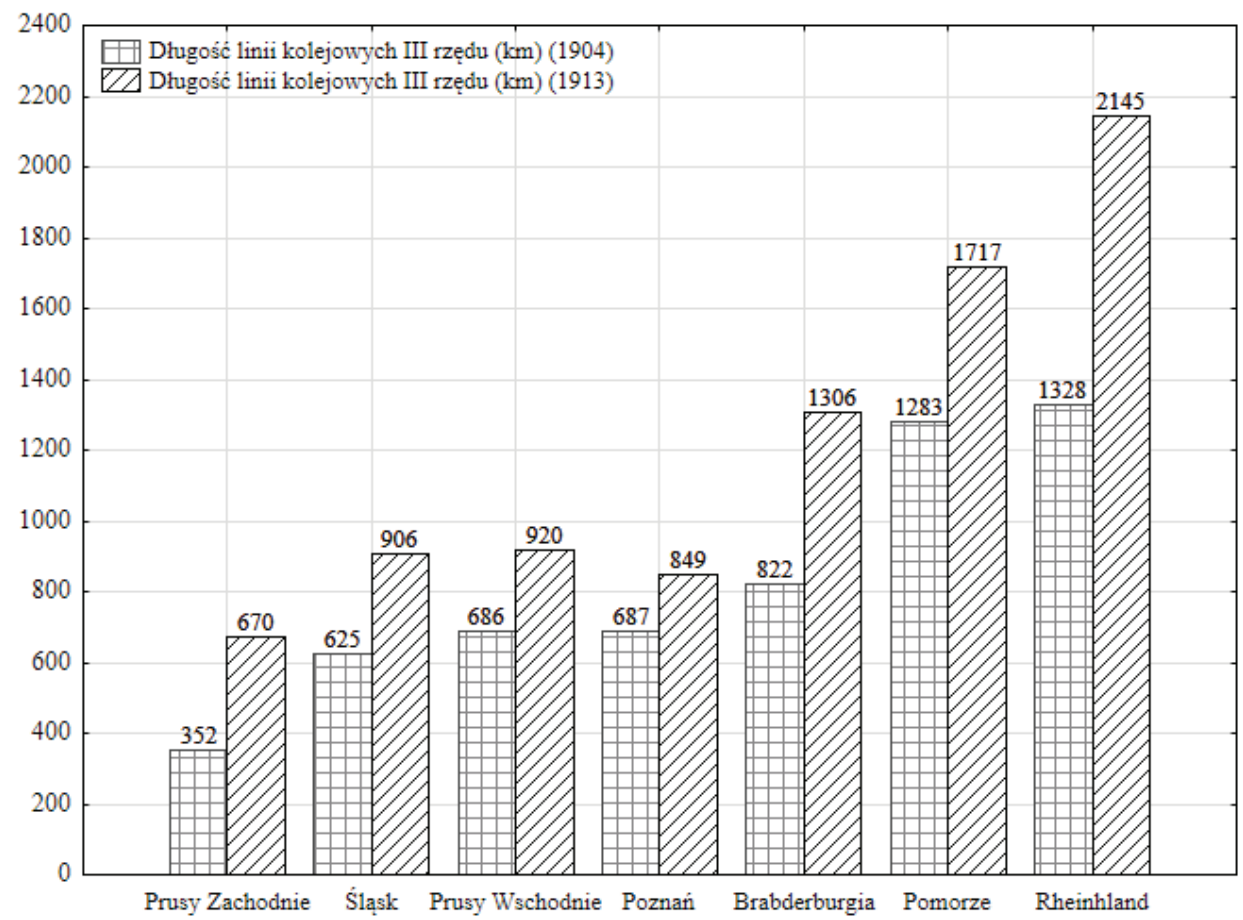

Rys. 5. Długość linii kolejowych III rzędu w wybranych prowincjach Królestwa Prus (km) (1904, 1913).

Źródło: Opracowanie własne na podstawie: Statistisches Jarbuch für den Preussische Staat, Königlischen Statistischen Buerau, Berlin 1904, s. 106; Statistisches Jarbuch für den Preussische Staat, Königlischen Statistischen Landesamt, Berlin 1915, s. 258.

Do roku 1913 w prowincji Pomorze wybudowano łącznie $2352 \mathrm{~km}$ linii kolejowych (6,3\% ogółu szlaków w Prusach), w tym: 785 km linii głównych (3,9\% linii w Prusach) i $1486 \mathrm{~km}$ linii bocznych (9,8\% linii w Prusach). Prowincja była

${ }^{34}$ Por. A. Geißler, Nutzung regionaler Handlungsspielräume für den Ausbau der Instrastruktur: Der Bau regionaler Bahnen in Pommern 1880-1914, (in:) Veröffentlichungen der historischen Kommission für Pommern, V. 43., Pommern im 19. Jahrhundert, Köln, s. 289. 
pod względem długości szlaków kolejowych przypadających na $1000 \mathrm{~km}^{2}$ na ostatnim miejscu w stosunku do wszystkich pruskich prowincji (wobec średniej dla Prus: $108 \mathrm{~km} / \mathrm{km}^{2}$ ). Podobną gęstość miała tylko prowincja Prusy Wschodnie $\left(78,3 \mathrm{~km} / \mathrm{km}^{2}\right.$ powierzchni).

Liderzy - uprzemysłowione prowincje zachodnie: Rheinland $(176 \mathrm{~km} /$ $\left.1000 \mathrm{~km}^{2}\right)$, Westfalen $\left(167 \mathrm{~km} / 1000 \mathrm{~km}^{2}\right)$. Stąd też rozbudowa kolei III rzędu była niejako koniecznością i w jakiś sposób uzasadnia prym w tej dziedzinie Pomorza.

Pozostaje jednak prawdą, że koleje wąskotorowe mimo tego, że na trwałe wkomponowały się w krajobraz prowincji i były dobrym przykładem współpracy władz samorządowych, były niskodochodowe, w znacznej mierze nasilenie użytkowania łączyło się z dużą sezonowością prac w rolnictwie, i kolejnymi kosztami użytkowania, które należało pozyskiwać ze źródeł publicznych.

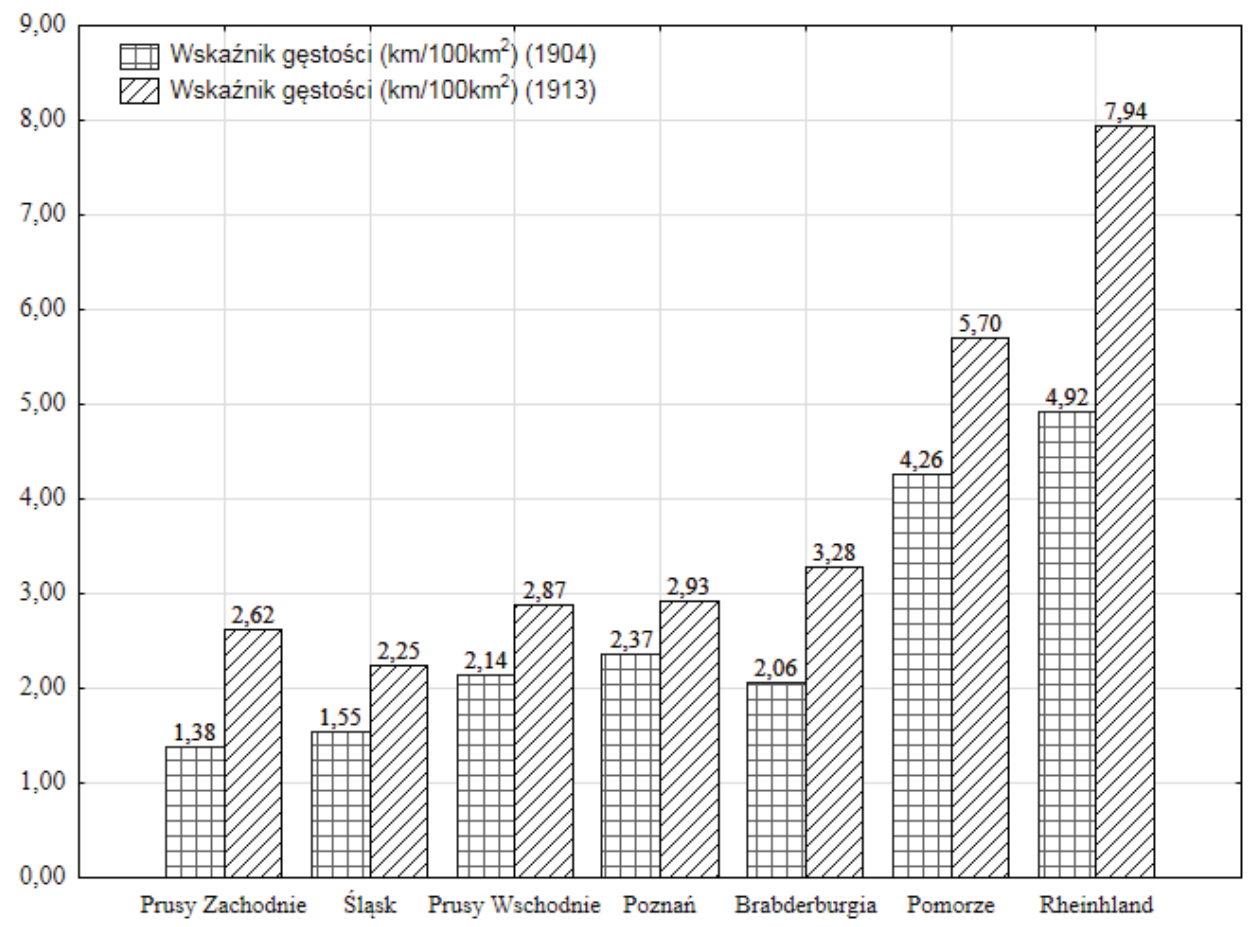

Rys. 6. Wskaźnik gęstości linii kolejowych III rzędu w wybranych prowincjach Królestwa Prus $\left(\mathrm{km} / 100 \mathrm{~km}^{2}\right)(1904,1913)$.

Źródło: Opracowanie własne na podstawie: Statistisches Jarbuch für den Preussische Staat, Königlischen Statistischen Buerau, Berlin 1904, s. 106; Statistisches Jarbuch für den Preussische Staat, Königlischen Statistischen Landesamt, Berlin 1915, s. 258; Statistisches Jahrbuch für das Deutsche Reich, Wyd. Kaiserlichen Statistischen Amte, Berlin 1913 (34), s. 1. 


\section{Wnioski}

Koleje były bez wątpienia jedną z ważniejszych innowacji technologicznych w warunkach XIX wieku. Ten środek transportu w tym stuleciu wywarł ogromny wpływ na ożywienie gospodarcze wielu krajów, w tym i regionów słabo zaludnionych, rolniczych, oddalonych od wielkich aglomeracji i zacofanych gospodarczo, jak pruska prowincja Pomorze.

Okres rozbudowy linii kolejowych umożliwił stworzenie wielu miejsc pracy zarówno przy samej budowie, obsłudze, ale także dał impuls dla rozwoju wielu dziedzin przemysłu, łącznie z przemysłem maszynowym, hutniczym itd.

Budowa szlaków kolejowych w Prusach w pierwszych dziesięcioleciach ich istnienia była efektem zaangażowania przede wszystkim sektora prywatnego, który zaangażował ogromne środki finansowe (1860 r. - 262,5 mln Thr). Państwo ograniczało się początkowo do regulacji prawnych. W przyszłości rozbudowa kolei wywarła wpływ na aktywne uczestnictwo sektora publicznego (1860 r. - $89 \mathrm{mln}$ Thr). Nie bez znaczenia pozostawało znaczenie kolei w działaniach militarnych, a także w migracji ludności. Państwo pruskie aktywnie włączało się w proces budowy kolei na początku lat osiemdziesiątych XIX wieku, zaś w szczególności władze lokalne od 1892 roku, co miało związek z nową ustawą dotyczącą budów kolei wąskotorowych (Kleinbahnen). Władze lokalne, stawały się aktywnym uczestnikiem życia gospodarczego, w tym rozwoju infrastruktury, a wymiernym dowodem jest rozwój linii kolei III rzędu.

Kolej Berlińsko-Szczecińska i powstałe odcinki szlaków kolejowych w wyniku jej zaangażowania przyczyniły się do rozwoju regionu, ukazując także znaczenie miasta portowego Szczecin. $Z$ kolei linie boczne i trzeciego rzędu rozwijały się dzięki wsparciu lokalnych środowisk (prowincji, powiatów) i rządu centralnego, ale także inicjatyw prywatnych, umożliwiając przy użyciu dużo mniejszych nakładów finansowych na rozprzestrzenienie się kolei lokalnych (budowa $1 \mathrm{~km}$ linii III rzędu była niemal dziewięciokrotnie tańsza). Prowincja Pomorze, choć wiodąca pod tym względem, nadal pozostawała w zasadzie za wyjątkiem Szczecina prowincją zacofaną gospodarczo, ze słabo rozwiniętą infrastrukturą komunikacyjną. 
Janusz Myszczyszyn

\section{THE CREATION AND DEVELOPMENT RAILWAYS ON THE EXAMPLE OF POMERANIA PROVINCE AS AN EXAMPLE OF THE ACTIVITY OF LOCAL COMMUNITIES AND THE PUBLIC SECTOR}

The creation and development of railways in Prussia in the first two decades of their existence occurred by the private sector. Prussian state established railway law on 3 November 1838, the Berlin-Szczecin railway built relatively early line Berlin-Szczecin (1843) and Stargard-Szczecin (1846).

Development of the railway was an important event for the province and Szczecin, affecting the economic, social and political importance.

Prussian government has been actively involved in the process of construction of the railway in the early eighties of the 19th century. Local government have been active since 1892, which was related to the new law on local railways construction (Gesetz über Kleinbahnen und Privatanschlußbahnen vom 28.07.1892). Local authorities (eg. provincial assembly, counties, local municipalities) became an active participant in economic life, including the development of narrow-gauge railway infrastructure in Pomerania.

Słowa kluczowe: koleje, koleje wąskotorowe, Berlin-Stettiner Eisenbahn, znaczenie gospodarcze kolei, prowincja Pomorze.

Keywords: railway, narrow-gauge railway, Berlin-Stettiner Eisenbahn, economic importance of railway, Pomeranian province.

\section{BIBLIOGRAFIA}

Achilles W., Die Landwirtschaft in Preussen in den Grenzen des wissenschaftlichen Erkenntnisstandes und der Ausbildung vor dem Ersten Weltkrieg, [w:] Wirtschaft, Wissenschaft und Bildung in Preußen, red. K. Kaufhold, B. Sösemann, Stuttgart 1998.

Behm E., Die modernen Verkehrsmittel: Dampfschiffe, Eisenbahnen, Telegraphen; eine geographisch-statistische Übersicht mit historischen und volkswirtschaftlichen Notizen mit einer Telegraphen- und Dampfschifffahrts-Karte der Erde und einer Kommunikations-Karte von Central-Europa, Gotha 1867.

Czapliński W., Galos A., Korta W., Historia Niemiec, Wrocław-Warszawa-Kraków-Gdańsk 1981.

„Das Königlich Preußische Eisenbahngesetz” vom 3. November 1838, Elberfeld.

Deutsche Eisenbahn-Statistik für das Betriebs-Jahr 1862, Berlin 1864.

Fishlow A., American Railroads and the Transformation of the Antebellum Economy, Cambridge, MA: Harvard University Press 1965.

Fogel R., A Quantitative Approach to the Study of Railroads in American Economic Growth: A Report of Some Preliminary Findings, ,Journal of Economic History” 1962, 22, 163/197.

Fogel R., Railroads and American Economic Growth: Essays in Econometric History. Baltimore 1964.

Fremdling R., Eisenbahnen und deutsches Wirtschaftswachstum 1840-1879. Ein Beitrag zur Entwicklungstheorie und zur Theorie der Infrastruktur, Dortmund 1985. 
Geißler A., Nutzung regionaler Handlungsspielräume für den Ausbau der Instrastruktur: Der Bau regionaler Bahnen in Pommern 1880-1914, (in:) Veröffentlichungen der historischen Kommission für Pommern, V. 43, Pommern im 19. Jahrhundert, Köln.

Grabska W., Ekonomiczna ekspansja Niemiec na Wschód w latach 1870-1939, Wrocław-Warszawa-Kraków 1964.

Hölzinger M., Strategische Bedeutung von Lobbyarbeit im Spiegel der historischen Entwicklung der verkehrspolitischen Rahmenbedingungen in Deutschland: Handlungsmöglichkeiten für das Lobbying im Unternehmensinteresse der DB AG im Politikfeld Raumordnung, Trier 2002.

Jahrbuch der Provinz Pommern, Zehnete Aus., Verlag von Th. von Nahner, Stettin 1857.

Jarbuch für die amtlische Statistik des Preussischen Staats, Berlin 1863.

Kasten G., Ein Rittergut im Wandel der Zeit. Erinnerungen an das pommersche Dorfleben und ad die Zeit bis 1957, Norderstedt 2009.

Koziarski S., Sieć kolejowa Polski, Opole 1993.

List F., Über ein sächsisches Eisenbahn-System als Grundlage eines allgemeinen deutschen Eisenbahn-Systemes, und insbesondere über die Anlegung einer Eisenbahn von Leipzig nach Dresden, Leipzig 1833.

Matschoss C., Ein Jahrhundert deutscher Maschinenbau: von der Mechanischen Werkstätte bis zur Deutschen Maschinenfabrik 1819-1919, Berlin 1919.

Mellies D., Modernisierung in der preußischen Provinz?: Der Regierungsbezirk Stettin im 19. Jahrhundert, „Kritische Studien zur Geschichtswissenschaft”, Göttingen 2012.

Mielcarek A., Transport drogowy, wodny i kolejowy w gospodarce prowincji pomorskiej w latach 1815-1914, Szczecin 2000.

Myszczyszyn J., Koleje żelazne, jako istotny element procesu wstępnej industrializacji państw niemieckich, „,Kultura i Historia” 2010, nr 17 - http://www.kulturaihistoria.umcs.lublin.pl/archives/1757 (dostęp: 1 III 2014).

Myszczyszyn J., Protekcjonizm agrarny jako czynnik utrudniajacy rozwój przemystu w Prusach w końcu XIX w. i początkach XX w. na przykładzie prowincji Pomorze, [w:] Z dziejów przemystu przed 1945 rokiem, red. J. Chumiński, M. Zawadka, Wrocław 2012.

Myszczyszyn J., Rozwój transportu i wymiany międzynarodowej a pierwsza fala globalizacji gospodarczej, „Kultura - Historia - Globalizacja” 2014, nr 15.

Myszczyszyn J., Wplyw kolei żelaznych na wzrost gospodarczy Niemiec (1840-1913), Łódź 2013.

Myszczyszyn J., Znaczenie Niemieckiego Związu Celnego w budowie jedności gospodarczej Niemiec, „Kultura i Historia" 2010, nr 18.

Pommern Jahrbuch, Stettin 1928.

Rostow W. W., The Stages of Economic Growth - A Non Communist Manifesto, Cambridge 1960.

Statistisches Jarbuch für den Preussische Staat, Königlischen Statistischen Buerau, Berlin 1904.

Statistisches Jarbuch für den Preussische Staat, Königlischen Statistischen Landesamt, Berlin 1915.

Ten F., Eisenbahnen und Eisenbahnunternehmer in der Industriellen Revolution. Ein preussischldeutsch-englischer Vergleich, „Kritische Studien zur Geschichwissenschaft”, Bd. 120, Göttingen 1997.

Włodarczyk E., Główne linie dziejów Pomorza Zachodniego w latach 1815-1945 r., Szczecin 2001.

Włodarczyk E., Wielki przemyst Szczecina w latach 1850-1914, Warszawa 1982. 